\title{
Stronghold Cities. Dystopian Fears in Utopian Asylums in Audiovisual Narratives
}

\section{Ksenia OlKusz}

\begin{abstract}
In the past few years there has been a growing interest in depicting permanently sieged strongholds, secluded last stands, or quarantined asylums within a post-apocalyptic world so as to strengthen the sense of the ultimate isolation and disconnection from the desolated world outside. The majority of those narratives share a similar world-model, featuring an over-crowded, fortified refuge and its ruler turning a utopian sanctuary into a dystopian confinement. This means that the society in such a world faces two actual threats: one imminent, be it a zombie apocalypse, bands of scavengers, or epidemic that forces people to take refuge - and the other one, concealed, which reveals itself when everything seems to be under control.
\end{abstract}

Keywords: dystopia, game, movie, narrative, utopia

Ksenia OLKUSz is a literary historian, critic, and theorist; she is assistant professor at the head of Facta Ficta Research Centre in Kraków as well as editor-in-chief of open access Facta Ficta Journal (factafictajournal.com); she has authored books Wspótczesność w zwierciadle horroru. O najnowszej polskiej literaturze grozy [The Contemporaneity in the Mirror of Horror: On the Newest Polish Gothic Fiction] (2010) and Materializm kontra ezoteryka: drugie pokolenie pozytywistów wobec "spraw nie z tego świata" [Materialism versus Esotericism. The Second Generation of Polish Positivists and the Otherworldly] (2017) as well as edited volumes Zombie w kulturze [Zombies in Culture] and Światy grozy [Worlds of Terror] (2016), and also More After More. Essays Commemorating the Five-Hundredth Anniversary of Thomas More's Utopia (2016); since 2016 she has been also the leading editor of the series "Perspektywy Ponowoczesności" ["Perspectives of Postmodernity"] and supervisor of all Facta Ficta Research Centre publishing projects; her research interests span across popular culture, postclassical narratology, literature studies, dystopian studies, horror, gothic, and crime fiction. E-MAIL: ksenia.olkusz@factaficta.org 


\section{Apocalypse and its social consequences in video games and movie narratives}

Apocalyptic screenplays are based on the assumption that as a consequence of an event which has had a global effect (a pandemic, the spread of a virus that transforms people into zombie, a total war, nuclear disaster, etc.) all sorts of treaties between states are broken and there follows destabilization within the structures of armies, police forces or other organizations dealing with regulation and the execution of rights. As a result,there follows a collapse within social hierarchies, which leads to slackening of polities to date, as well as the appearance of new structures of power, most often realized ona micro scale. An example of these are stronghold cities as micro-communities, either completely isolated from external influences or connected with one another to make one co-functioning organism. The first of the mentioned systems is present in such series as The Walking Dead (AMC 2010), Z Nation (SyFy 2014), The10o (based on the book by Kass Morgan, published under the same title in 2013, produced as a series by The CW 2014), The Last Ship (based on the book by William Brinkley, entitled The Last Ship, published in 1988, produced as a series by TNT 2014), or Falling Skies (TNT 2011-2015), in movies: Warm Bodies (directed by Jonathan Levine, USA 2013, based on the book by Isaac Marion, published under the same title in 2010), The Book of Eli (directed by Albert Hughes, Allen Hughes, USA 2010), Mad Max: Fury Road (directed by George Miller, USA 2015), in games: Mass Effect 3 and in many less popular games set in a zombie-centric reality. In turn, the other type of stronghold cities include the ones featured in the series Dominion (SyFy 2014, inspired by the movie Legion by Peter Schink and Scott Stewart, 2010), which - indeed - do form separate political forces, yet remain in cooperation with one another to a lesser or greater extent. On the other hand, those found in the game The Last of Us (produced by Naughty Dog, 2013) are linked with one another through a centralized system of power wielded by the military organization Firefly and are managed mainly by one person, Melanie (who strives to extract antibodies from the organism of a teenage character named Ellie infected with zombieism)

It is worth noting that the presentations of the rules of the establishment or the functioning of new constructs of power are, in many narratives, unusually similar, showing certain defined regularities, according to which survivors who are in need of a guarantee of safety start concentrating around 
a strong individual or a group managed by one. They acknowledge the person or the group to be natural leaders. In this way, a chain of dependences forms which then shape relations within the group, and it is the leader's personality and aspirations, or emotional needs that shapes the character of the given micro-community. An individual inclined towards authoritative wielding of power, often having remained on the margin so far or having played functions of little importance in the community, psychologically disturbed or frustrated because of his/her own personal or professional situation, is depicted by the authors of such narratives as an individual who is gradually intoxicated with the power he/she holds and more and more willing to wield it. The pathology of behaviours connected with the questions of having control over a group lies at the foundation of micro-dystopia in texts of culture, which deal with describing the annihilation of mankind.

It is also clearly seen that the rules of constructing community complexes, which are manifested in the fictitious reality, are akin to genuine mechanisms of establishing totalitarian power in its most basic dimension, which is exemplified in plots set in a post-apocalyptic world. The creators of these narratives are clearly inspired by elementary determinants of dependences present within groups, merely amplifying certain mechanisms to make them more attractive to the recipient. Similar dependences have been analysed by, among others, Todd K. Platts, who devoted an essay to zombie-centric narratives (although his remarks can be expanded to relate to many plots of post-apocalyptic provenance). The author states that

Although much has been studied, there are important areas that have been neglected and ways that sociology could lend unique and critical insight into current zombie research. I use the remainder of this essay to highlight three such avenues of inquiry. These points of departure acknowledge three important insights in the sociological study of popular culture. First, cultural productions reveal something about the societies that created them, and patterns emerging from the content of cultural productions partly unsheathe underlying structural patterns of those societies. ${ }^{1}$

1 T. K. Platts, Locating Zombies in the Sociology of Popular Culture, p. 547-560. 


\section{The psychically unstable: portraits of tyrants in micro-dystopias}

As observed earlier, the adversaries of the protagonists (fighting the existing hegemonic system or one being created) are typically despots and acolytes concentrated around the former, who represent personality types similar to that of their leader - or, alternatively, weak individuals who are willing to share the well-being offered to them by the tyrant at all costs. Since postapocalyptic narratives do - in a sense - reflect very concrete mechanisms underlying the formation of systems or social groups facing a threat, the authors cannot avoid creating such a type of a hero that would both fit the described reality and possess a psychological profile to make a peculiar authentication possible. In a similar context, it is not surprising that the figure of despot is identical with the profiles of psychopaths or sociopaths thatappearextremely frequently in popular culture. Here, it is worth paying attention to the fact that the above-mentioned images form separate categories, since - as researchers argue - "a sociopath acts appropriately in a social setting. A psychopath's impulsive and plucky nature often makes them incapable of understanding social norms. They have either next to little, or no control over naturally fickle temperaments" ${ }^{2}$. It is also worth quoting a slightly more optimized definition of psychopathy, as proposed by June Price Tangney and Jeff Stuewig, who write:

The term sociopath is sometimes used instead of psychopath. The term of choice sometimes reflects the belief about the origins of the conditions; other times it reflects habit or training. Criminologists and sociologists often use the word sociopath because they believe that social forces create the condition. Those who take a more psychological, biological, and genetic approach may use the term psychopath. Essentially, however, the traits and behaviors that describe these individuals are the same no matter which term is used. Researchers using Hare's PCL-R [Psychopathy Check List - Revised - K.O.] use the term psychopath to refer to individuals who score at or above a specified cutoff ${ }^{3}$.

2 J. Gabay, Brand Psychology: Consumer Perceptions, Corporate Reputations, p. 331.

3 J. P. Tangney, D. V. Blalock, J. B. Folk, J. Stuewig, Evil Persons or Evil Deeds? What we've Learned about Incarcerated Offenders, p. 327. 
In the context of micro-dystopia, it is primarily the features attributed to sociopaths and psychopaths that define their relations with people According to researchers, including Jonathan Gabay,

Psychopaths lack recognizable moral codes of ethics. Highly manipulative, they don't feel empathy. Their lifestyles are mostly parasitic. In contrast sociopaths can experience guilt. However, they are only prepared to open up emotionally to a small circle of people. Beyond this handpicked group, a sociopath behaves similarly to a psychopath - equally dismissing common social principles. On the other hand a sociopath isn't inclined to cheat or manipulate people - especially cherished family members or friends. ${ }^{4}$

So, indeed, many observations relating to regularities in the behaviour of sociopaths and psychopaths find their reflection in texts of culture, which present a given type of hero-leader of a micro-community. The portraits of autocrats are - because of this - very strongly marked, revealing the creators' overall predilection for using determined (and none too sophisticated) psychological character models. A similar artistic solution, however, is realized in a variety of frameworks, providing an impulse - on the one hand for presentations based on stereotypes and clichés and - on the other one for enriching such presentations with individualized details.

Emotional liability can be found, for instance, in the case of Carnegie in the movie The Book of Eli - a man obsessed with obtaining a copy of the Bible. This goal becomes a supreme mission of the despot who - not heeding the people accompanying him - sacrifices their lives in pursuit of the supposed owner of the book. The distinctive features of the tyrant are, obviously, his inclination towards violence, control of citizens by means of a rewards and punishments system, as well as aggression in relations with his inferiors.

An interesting realization of the motif of a tyrant is also the figure of the Governor in the series The Walking Dead. In the episodes of Season 3 (2013) Philip Blake, also known as The Governor, a sociopathic leader of the city of Woodbury, lures citizens with a pre-apocalyptic illusion of normality, while simultaneously disposing of any rebellious individuals at will - all of which takes place in the face of a zombie nightmare, therefore transforming a

4 J. Gabay, op. cit., p. 332. 
utopian promise into a dystopian lockout. It is noteworthy that the portrait of the despot is delineated in a very elaborate manner - with the use of details which compose a penetrating study of a man who reveals his true nature under the influence of the current status quo. The zombie epidemic has changed a frustrated man, full of complexes, into a decisive individual, determined, thirsty for power, and willing to use violence, who - at the same time - hides a dark secret under a mask of remaining unemotional - his niece transformed into a living corpse that needs to be fed with fresh meat. This dictator, playing freely with human existence, displays such features as: inclination towards violence, vengefulness close to madness, and obsessivecompulsive behaviour. However, Blake tends to act in compliance with the psychological model of a sociopath posited, among others, by Martha Stout, who claims that: "if anything, people without conscience tend to believe their way of being in the World is superior to ours" 5 .

Sean Ramsey - the leader of the sect resistant to Red Flu virus, who appears in the series The Last Ship, ${ }^{6}$ is governed by very similar motivations. The ex-captain of a British submarine is convinced of his exceptionality to the degree that he sends a scientist infected with the virus (but resistant to it) to enclaves where the survivors are staying. Selection is made in a natural way, since only $5 \%$ of the population avoid being infected. Everybody who manages to survive is indoctrinated by Sean and his accomplices to become subsequently convinced of their own exceptionality and the role which they will play in the new society free from the weakness of the former one. Sean believes in Darwinian laws, acknowledging individuals resistant to the virus to be indeed super-humans and to have the right to decide about the shape of the new reality. Thus, the very hero grants to himself the right to fight the crew members of the destroyer "USS Nathan James" and their allies who strive to produce and distribute medicine. Sean takes the decision to bombard the laboratories where the vaccine is produced, murdering the researchers and doctors in order to prevent the distribution of the antidote, break the social structures, and prevent their likely rebuilding. When the attempt to recruit and convert Jeffrey Michener, the running President of the USA, fails, Sean tries hard to stop the crew of the "USS Nathan James" from distributing the medicine by broadcasting unclear information accusing the ship commanders of treason - and that there is no vaccine to prevent infec-

5 M. Stout, The Sociopath Next Door, p. 50.

6 The second season (2015). 
tion with Red Flu. Therefore, it is clearly seen that the personal goals and appetites of the dictator take priority over the good of the common people, which forces the protagonist to try controlling his inferiors at all costs and to build his own order abstracted from the status quo.

Similarly, the previously mentioned series (the final part of its first season and the beginning of the second one), takes place in the stronghold of Baltimore, where the vice-chair of the US President's Defense Policy Board, Amy Granderson, with the help of loyal police service, tries to realize her own version of or derbased on the principles of revitalization of society by protecting the most valuable individuals as well as educating the young survivors and forming them according to predetermined models - all of which is of paramount importance for reducing the number of the infected. The ill are commonly encouraged to report at quarantine points, having been promised to have their living conditions improved and to be given the chance to be cured. The very same places, however, serve the purpose of ultimately eliminating the infected and those accompanying them, with the aim of obtaining energy from their corpses, which turns out to be necessary to produce fuel. A significant element of the policy run by the despot-woman is the assumption that only "worthy" people should survive, that is ones whose contribution to the subsequent development of civilization is unquestioned.

It ought to be mentioned here that the artistic hyperbolization of the negative features of a tyrant aims, first of all, to amplify the dramatic effect of situations and justify the downfall of the dictatorship in the end. Moreover, showing the vicissitudes of protagonists in the perspective of struggling against tyranny offers additional appeal or enrichment to both the plot and the character portrayal.

\section{Principles behind the functioning of a strong- hold city}

In the characters' representation, taking shelter from external threats is identical with a guarantee of security; however, there is also a danger within this allegedly familiarized territory. This simple mechanism of questioning the solace of asylum and breaching its borders - the same process, for instance, as in a classical horror plot - is of supreme importance here, as it shapes the heterotopian dichotomy of space. Indeed, fear-related impressions are 
doubled as a result of the occurrence of an external threat represented by zombies, epidemics, viruses, alien invaders, supernatural beings etc., as well as an internal one, personified in the figure of a tyrant.

Thus, the "alien" incarnated in a despot becomes the central point of micro-dystopia, which conditions the principles of its functioning. Terror does not come exclusively from outside an alleged asylum, but is made present within its confines, thereby turning it into a trap. Consequently, the protagonists must find a way to escape. This double reversing of the order of reality is all the more acute as it concerns a supposedly familiarized space, where characters traumatized by apocalyptic events and looking for a substitute of "normality" - that is simply an escape from nightmares - can find themselves.

Therefore it is very important for the authors to create an initial atmosphere of harmony, which turns out to be illusive in the light of repeating incidents featuring demonstrations against despotic forms of governance. A fine example could be the underground stronghold city of Charleston in the TV series Falling Skies. In the second season, the protagonists who are exhausted by a long, drawn-out fight against an alien race of invaders, and finally by the loss of their dearest, finally manage to reach the destination of their peregrination - an apparently quiet place governed by reasonable people, the underground of Charleston - a city itself completely destroyed by aliens. The initial euphoria at the sight of clean rooms, food rich in nutrients, separate lodgings equipped with beds with fragrant bedding, wanes almost completely immediately after they manage to settle in. The 2nd Mass i.e. The 2nd Massachusetts Militia Regiment - are deprived of weapons, reinforcement from civilians who are not allowed to join their ranks, while a gang called the "Berserkers", serving the militia as scouts, is arrested under a trivial pretext, as a group which does not suit the vision of the community that is projected by the leader - Arthur Manchester. He, in turn, having worked as a university lecturer before the war with the Aliens, due to his profession (he is a historian specializing in the American War of Independence) and dedication seems to firmly believe in the mirage of a repetition of events that happened 230 years previously. He tempts the main protagonist, Tom Mason, with a vision of becoming another Jefferson and Washington. Mason, skeptical about the plans to form a community which avoids struggle, starts to realize that within the stronghold there can only be a fight for power. Both he and his life partner, Anne Glass, are warned that everyday life in 
the stronghold city differs from the existence which they have dreamed of. The sumptuous meals which they were fed the day before are only part of a welcome and each slip or inappropriate words are carefully noted to serve subsequently as a basis for different legal consequences depending on the weight of the offence. The daughter of the current commander of the and Mass informs the couple that it is only due to the great merits and combat value of the regiment that they have been given spacious quarters while the others must be satisfied with sharing their lodgings with a few strangers.

In the series The 10o, the stronghold in Mount Weather is presented in a similar way. After a global nuclear war, people hide in the bunker in Mount Weather, under the auspices of Dante the President, and, after 97 years of quarantine, begun harvesting for radiation-immune Grounders to execute blood transfusions essential for sustaining their long-term presence outside the bunker. A dystopian motif arises later on, when it becomes clear that the Mountain People feed the Grounders with their own kin and also force them to hunt more Grounders for further transfusions - which is kept secret from the uninitiated part of the society and Grounders alike. Nevertheless, the opening sequences do not show whatever is hidden under the pretence of harmony. The young people brought to Mount Weather initially see only spacious, warmly lit interiors, eat elegantly prepared meals in the canteen, and admire the works of old masters hanging on the walls to the accompaniment of comforting classical music flowing from discreetly installed loudspeakers. All these elements are designed to create a sense of harmony and safety, of which the authorities of Mount Weather assure the protagonists who have come from Arks situated in the Earth's orbit, unaware of the real politics of Mount Weather. However, the main heroine, Clarke, distrusting and extremely sensitive to nuances, very quickly perceives flaws in this ideal social construct. The group of survivors owes the kind reception not to the exceptional kindness or special concern of the natives, but to the medical plans of the latter who want to use the survivors' bone marrow for selected stronghold inhabitants. The outsider's marrow, because of its long exposure to radiation and - as a result - increased resistance to it, is supposed to make it possible for the Mountain Men to leave their shelters and return to the surface of the Planet, which has been unworkable so far.

An illusion of security is also offered by the station meaningfully named the Sanctuary, featured in the game Mass Effect 3, luring exiles with the vision of stability in a zone free from war. The isolated space is expected to serve 
as a place of asylum and provide maximum comfort to its visitors, which is communicated through loudspeakers. This message is, however, complemented with a rather ambiguous order for those entering to leave all their belongings behind and a prohibition to keep any communication devices. The player realizes the falsity of the station policy very quickly, though, since the heroes appear in the place shortly after it has been attacked by the alien race of mechanical harvesters hunting for all the living - the Reapers. It turns out that the fortress is not designed to protect the exiles but to use them for transformation into Husks - synthetic organic zombies bound to the will of the Reapers. The organization Cerberus is responsible for the whole mystification, as they lure unaware visitors to make genetic modifications in the experimental facilities by means of Reaper technology. It is worth remarking that "Cerberus supports the principle that any methods of advancing humanity's ascension are entirely justified, including illegal or dangerous experimentation, terrorist activities, sabotage and assassination" 7 , which results from the conviction that "Cerberus core belief is that humans deserve a greater role in the galactic community" ${ }^{8}$. The authorities of Sanctuary admit, however, that cheating is indispensable here from the point of view of carrying out research as soon as possible, without perceiving flaws in the course of their own reasoning.

Seemingly, the situation in Woodbury - the little town in the series The Walking Dead - is short of idyllic, since clashing with the brutal reality of the world controlled by zombies, although it appears to be the safest place. Notwithstanding, Julia Round in her article The Horror of Humanity comments on this illusive welfare: "Woodbury is an inauthentic society, in many ways more reminiscent of pre-zombie priorities" 9 - which can refer not so much to the drive towards preserving the illusion of normality from the time before the apocalypse as to problems of maintaining the power and supervising control over the inhabitants.

Illusions of well-being are also present in the case of women from the special enclave featured in the series $Z$ Nation. The place, reached by the main characters who are tired of avoiding zombies and who are in need of some respite, seems to be an idyllic asylum, wherein the contrast between what is outside (desert landscape, heat, dusty empty roads) and what is in-

\footnotetext{
7 Mass Effect Wiki [www 01].

8 Ibidem.

9 J. Round, The Horror of Humanity, p. 162.
} 
side (clean, quiet, perfectly kept houses, beautifully composed garden space, flowing streams, birds singing) creates an impression of safety offered by the asylum. Yet, it turns out that it is reserved exclusively for women, since the woman-leader - previously wronged by men - decides to refuse the latter the right to stay in this safe zone. She claims that the masculine element destroys harmony, provokes aggression, and all those aspects of life which - in her vision of well-being - cannot co-function. The rules which are enforced in the asylum not only isolate women from men, but allow full indoctrination of the newly-arrived women. Addy Carver, a traumatized girl, realizes this when she finds herself in the asylum together with her companions and whom Helen, the leader of the quasi-sect, persuades to stay and turns against her friends. Among the principles behind the functioning of the strongholdasylum, the need to keep men outside takes precedent, sometimes taking on a very radical form which reveals the true nature and state of Helen's demoralization. Not only does she forbid men from entering the territory of women, but also has all boys who have turned fourteen leave the place, which - obviously - entails their imminent perishing at the hands of zombies. As a matter of fact, every man whom Helen assesses to be aggressive or capable of violence against women is threatened with death. The women living in the asylum regularly go hunting for men who harm women to take revenge in the cruelest of manners. In the episode entitled Sisters of Mercy (So1E11), the apprehended males are chained to one another and one of them is shot down to put him through the process of zombification just to let the other companions be attacked, infected, or devoured. Such a stark contrast between the idyllic atmosphere of the shelter and the real foundations of its politics is all the more straightforward as newly-arrived women are invited to the asylum to participate in those murders. The act of murdering is meant to strengthen the bonds with the leader, to cement a fuller identification with the rules which determine the existence of the stronghold and in consequence - to confirm the impossibility of subsequent living on their own. The pathology of this relation consists in the women who reside in the asylum gradually become completely dependent on Helen's will, unable to decide about their fate other than by referring to the group. The latter, on the other hand, forces them to act aggressively, to make ambiguous moral choices, as well as reducing the eventuality of escape by depriving them of contacts with their loved ones. 
In such a system, a despot evidently acquires features resembling the leader of a sect. As Michael Argyle states, "Sect leaders can also be authoritarian, control their group of followers by demanding obedience, sometimes by physical punishment, and impose considerable restrictions on their behavior" ${ }^{10}$. He is readily supported by Kenneth S. Bordens and Irwin A. Horowitz, who write: "All cults have many characteristics in common. The primary feature is a charismatic leader. He or she takes on a supernatural aura and persuades group members to devote their lives [...] to the cult" ${ }^{11}$. These descriptions are convergent with the psychological interpretation of dependences that regulate the functioning of communities in micro-dystopias. The hierarchical order which binds the citizens or refugees within many citystrongholds is reminiscent of sectary systems mainly because of the loss of individuality for the benefit of the group, a characteristic predilection towards social divisions and categorizing citizens according to their utility for the community. As Michael Argyle writes: "A sect may target a particular kind of person" 12 and this is compliant with the typical actions of dictators. This is also clearly observed in such series as The Last Ship and Z Nation where selected citizens are expected to create a new order, or in the image of social rules presented in the series Falling Skies (stronghold Charleston, asylum Chinatown), Dominion (city-stronghold Vega), Z Nation (a community of cannibals who exploit women to lure potential victims), or in Levine's movie Warm Bodies or even in Mad Max: Fury Road, where citizens are assigned to specific task groups.

It is also worth paying attention to the analogy that exists between the behaviour of sect members and the actions and choices made by inhabitants of city-strongholds - especially since "sect-type groups are probably helped by being given an identity as members of a spirituals élite, by an acceptable interpretation of their unprivileged position, and by cathartic group experience" ${ }^{13}$. The residents of some city-asylums surrender to authority of their own will, finding pleasure in worshipping the leader or maintaining the cult which the latter originated. An example of this system of rule is the asylum in Chinatown in the series Falling Skies, which is protected against alien (the Espheni)attacks by the presence of the hybrid Lexi (half-human half-alien),

\footnotetext{
${ }^{10}$ M. Argyle, Psychology and Religion: An Introduction, p. 172.

${ }^{11}$ K. S. Bordens, I. A. Horowitz, Social Psychology, p. 222.

${ }^{12}$ M. Argyle, Psychology and Religion..., p. 173.

${ }^{13}$ Ibidem, p. 249.
} 
who has at her disposal abilities acknowledged to be supernatural by the community. A cult develops around the young heroine and she herself begins to act as its leader. Unfortunately, Lexi cannot control her own emotions, which translates into her inability to control her powers - so, eventually, she leaves the asylum in order to join the Espheni. She kills the woman doctor Lourdes, who had been faithful to her and helped maintain her cult, and the followers who are left to themselves get killed during armed clashes.

In the series Dominion, control over the residents is held by means of a religion, which determines the functioning of the city and obedience of its citizens. It is worth observing that the people who are in authority themselves, remain abstracted from the faith, exploiting it cynically as a tool for manipulating the others. Communal prayers and denominational teachings are of the indoctrination ilk, adding a distinctive element to the life of the congregation that regulates social tensions. The hierarchic model within the community is conditio sine qua non to exercise control over it.

A similar regularity is also shown in the dieselpunk movie Mad Max: Fury Road, in which the sovereign authority over Joe's Citadel is in the hands of Immortan Joe, who makes the most distinctive example of a tyrant in the quasi-sect model. Here, the mechanism of control is, among others, water (called Aqua Cola), the distribution of which entirely depends on the despot. The whole process of offering the precious beverage is presented by the creators of the movie as a show, in which the main role is played by Immortan Joe - desiring admiration, longing for applause and adoration from his thirsty and starving citizens. The rocky city, a fortress in the desert where Immortan reigns is an example of a construct, in which each citizen has a defined role to play - from warriors to women giving birth to and feeding children. A significant element of this system is indoctrination, which consists in fixing in the consciousness of inferiors the importance of Joe is, how almighty and omnipotent he is, and what a privilege it is to be able to serve him. The natives subjected to the hegemon question neither his orders nor his very right to wield power. Dominated by the personality and charisma of the ruler, they respect each of his demands, ritualizing even the simplest of actions. The devotion of the warriors (called War Boys) is visible, especially during the moments when they struggle against their enemies. The strategy followed then is identical to acts of kamikaze, and the motivation for the young soldiers is their expected award which awaits them after death. Therefore, while carrying out suicidal missions they utter the same phrase 
"Witness me, brother" with one of the characters, planning to meet his death in combat, shouting as if in a trance: "I live, I die, I live again!".

Examples which illustrate the analogy between the hierarchy in a sect and authority in micro-dystopias show that initial danger is pushed to the background, while questions connected with the threat inside a stronghold city are exposed in the foreground. This internal danger is equivalent to breaking a determined taboo connoted by attributes like "asylum", "shelter" and - finally - "home". It should be added that many forms of wielding authority in micro-dystopian narratives are identical with methods applied in order to control citizens in totalitarian settings. Depersonalization resulting from the negation of the individual as an independent being, as well as attempts at indoctrinating community members are characteristic features of the model. Particularly the latter, as an interpretation of efforts directed towards the acceptance of a determined social order by heroes, constitute an element that builds the atmosphere of psychological terror. This hypothesis is exemplified by city-reeducation camps in the fourth season of Falling Skies, in which children captured by the alien are subjected to intensive training. The aim of the Espheni is to associate a sense of security with contact with the extraterrestrial race and simultaneously force the youngsters to denounce adult family members so that the alien could eliminate them from the fight. A vital component here is the attempt to construct a positive message which suggests that the order proposed by the Espheni is an ideal that should be aimed for. The illusive alliance between the human race and the alien makes a reference point of all slogans which the children have to repeat if they want to get food. The analogy to the Nazi youth structures in Germany is stressed here both visually (the children's and their trainers' clothing - style and colours) and verbally (the heroes draw attention to this concurrence in their talks several times).

To an even greater extent, the affirmation of a new order is underlined by the vice-chair of the US President's Defence Policy Board, Amy Granderson - the leader of the city-stronghold Baltimore in the series The Last Ship. There are, for example, schools functioning within this asylum, where young people are constantly reminded that they are the future of the nation and that they represent values which will become indispensable for a new society to function effectively (that is, patriotic values, devotion to leaders, carrying out the order to acquire knowledge, showing respect for authority etc.). Very similar methods of indoctrination are applied also by the authorities of 
city-strongholds resistant to Red Flu virus. The message is imprinted here by means of a simple psychological manipulation which consists in fixing the information through incessant repetition. The susceptibility to acceptance of similar beliefs is augmented by the trauma resulting from the loss of nearest and dearest, the omnipresence of death, the conviction that the world which used to exist will be annihilated completely. Those ruling the city-strongholds keep assuring the survivors that they have been chosen, are genetically better than those who did not manage to stay alive, that their duty is to create a new, stronger society which - resistant to Red Flu - will be more efficient and capable.

The lack of protest against such practices is closely connected here with the phenomenon of de-individualizing citizens. The higher the anonymity of the members of micro-communities, the more the refusal to perpetrate ethically reprehensible acts weakens. Social roles are assigned according to a pre-established hierarchy, becoming a constitutive tool of control and - at the same time - a point of reference in the event of any departures from the norm. It is the individuals and groups under whose authority a community is subjected that are entitled to the right of the stronger, which is connected with the belief that the feeling of belonging to a group provokes behaviours favouring one's own group. This happens, for example, in the series Dominion, in which the authorities of city-strongholds grant privileges solely to the chosen ones who have information at their disposal or hold a relevant social position. A similar phenomenon occursin Woodbury in the series The Walking Dead or in Z Nation, where, in the enclave of women, only the residents who unconditionally and are at all costs subordinated to Helen, their leader, are favoured.

Thus, people concentrated around the despot are not in power to oppose or negate the functioning of the system, since the situation in which they have found themselves does not favour such actions. Deprived of the possibility of revolting, they simply accept the reality and, with time, start manifesting behaviours which are identical with "a kind of a siege mentality", to quote Fred Standley ${ }^{14}$, so typical of dystopia and correlated with anti-individualism, when the freedom of a group is given priority over that of an individual.

Because of the practices applied by tyrants in order to maintain power, the alleged asylums become thus traps or prisons - territories from which escape is not possible. The only chance of regaining control and freedom

${ }^{14}$ F. Standley, Ever "More”: Utopian and Dystopian Visions of the Future 1890-1990, p. 126. 
is by subverting the existing order and installing a form of authority that may design a more optimal model of governance. Rebellion becomes possible, however, as a rule, due to external factors, understood as the germ of a rebellion and subsequent liberation from the power of the tyrant. Then a chain of events is sparked, which leads to loosening of the norms that govern a micro-dystopia. In The1oo, the inhabitants of Mount Weather are uncompromisingly defeated by the visitors from the Arks, in turn; in The Walking Dead, Woodbury is destroyed and in the next season, the Governor, who is trying to take his revenge and rebuild tyranny, gets killed. In The Last Ship, the despotic Amy Gardener's squads are liquidated and she herself is executed; in Dominion, the elaborately realized plans of the Camarils do not come off because of external forces (personified by fallen angels); in the game Mass Effect 3, the Reapers themselves ruin Henry Lawson's plans by openly attacking the Sanctuary and dismantling a carefully designed founding lie; in the movie The Book of Eli, Carnegie gets hold of the Bible in the end, yet, deprived of his strong protection and consumed by illness, he is defeated in the finale, as is Immortan Joe in Mad Max: Fury Road. Furthermore, Melanie from the game The Last of Us does not manage to extract the vaccine from Ellie's body, since the latter is saved from death by Joel, her trusty companion.

Meanwhile, Levine, in the movie Warm Bodies, proposes a somehow different solution by shoving Grigio to the background and allowing the hero to realize that a completely new order is setting in. Because the movie creates a rather positive effect, the figure of the heroine's father cannot simply be eliminated. On the other hand, the ideals he adhered to, those which regulated the everyday life of the stronghold city residents, are destroyed or repudiated.

\section{Conclusion}

The annihilation of civilization or mankind is never complete in postapocalyptic, micro-dystopian narratives. Although epidemics, cataclysms, or invaders from outer space do eliminate a considerable part of the population, "the end of the world rarely is the end, at least in popular culture. Instead, it's the beginning of a New World, a World that is Devoid of strong central government and traditional social institutions, and is populated with tougher 
than nails survivors" ${ }^{15}$. Similarly, there are narratives that make direct references to the motif of disintegration of structures of dystopian authority and establishment of totally new systems in their place.

Nevertheless, it is an particularly significant that the communities presented in various narratives are determined by identical circumstances, and their forms remain quite similar. This may result from the fact that the creators of plots are inspired by a set of defined regularities which exist in reality and are presented not only in publications with a sociological or psychological inclination, but also in popular-science literature. Obviously, the identical nature of certain narrative aspects or elements may take its roots in rules of the convention of the living dead storytelling (hence the schematic character of behaviours, motivations etc.). Still it is worth remembering that in such extreme situations especially, specific psychological models must constantly have their genesis in observations connected with interpersonal relations.

\section{Bibliography}

1. Argyle M., Psychology and Religion: An Introduction, Routledge, London, 2002.

2. Beit-Hallahmi B., Argyle M., The Psychology of Religious Behaviour, Belief and Experience, Routledge, London, 1997.

3. Bordens K. S., Horowitz I. A., Social Psychology, Mahwah, N.J. Lawrence Erlbaum Associates New Jersey, 2002.

4. Gabay J., Brand Psychology: Consumer Perceptions, Corporate Reputations, Kogan Page, London, 2015.

5. Platts T. K., Locating Zombies in the Sociology of Popular Culture, "Sociology Compass", 2013, no 7, pp. 547-560.

6. Stout M., The Sociopath Next Door, Tantor Medi, Old Saybrook, 2005.

7. Tangney J. P., Blalock D. V., Folk J. B., Stuewig J., Evil Persons or Evil Deeds? What we've Learned about Incarcerated Offenders [in:] The Social Psychology of Good and Evil, A. G. Miller (ed.), Guilford Press, New York, 2004, pp. 298-321.

8. Round J., The Horror of Humanity [in:] The Walking Dead and Philosophy: Zombie Apocalypse Now, W. Yuen (ed.), Open Court, Chicago, 2012, pp. 155-166.

${ }_{15}$ W. Yuen, Philosophy for the Dead, p. XIII. 
9. Standley F., Ever "More": Utopian and Dystopian Visions of the Future 1890-1990 [in:] More's Utopia and Utopian Inheritance, A. D. Cousins, Damian Grace (ed.), University Press of America, Lanham 1995, pp. 119-136.

10. Yuen W., Philosophy for the Dead [in:] The Walking Dead and Philosophy: Zombie Apocalypse Now, W. Yuen (ed.), Open Court, Chicago, 2012, pp. XII-XV.

\section{Internet sources used:}

[www 01] http://masseffect.wikia.com/wiki/Cerberus (access: 30.11. 2015). 